\title{
Detection of Bacterial Leaf Blight Resistance Genes in Indigenous Glutinous Rice Landraces
}

\author{
T. Thanh ${ }^{1}$, P.H. Ton ${ }^{1,2}$, V.D. Hai ${ }^{3}$, N.T. Luong ${ }^{2}$, T.V. Hai ${ }^{1,2}$, P.B. Hien ${ }^{4}$, \\ L.T. Nghia ${ }^{5}$, D.M. Trung ${ }^{6}$, N.T. Duong ${ }^{3}$, K.H. Trung ${ }^{3}$, T.D. Khanh ${ }^{3^{*}}$ \\ ${ }^{1}$ Biotechnology Faculty, Vietnam National University of Agriculture \\ ${ }^{2}$ Center for conservation and development of crop genetic resources, Vietnam National University \\ of Agriculture, Vietnam \\ ${ }^{3}$ Agricultural Sciences Institute, Hanoi, Vietnam \\ ${ }^{4}$ Department of Postgraduate Training, Vietnam Academy of Agricultural Sciences, Vietnam \\ ${ }^{5}$ Plant Resources Center, Hanoi, Vietnam; \\ ${ }^{6}$ Institute of Biomedicine and Pharmacy, Vietnam Military Medical University (VMMU), \\ Hanoi, Vietnam \\ e-mail: tdkhanh@vaas.vn
}

Keywords Blight leaf blight, resistant genes, glutinous rice landraces, Xa7 gene, Xa4 gene, Xa5 gene.

\begin{abstract}
Bacterial leaf blight disease (BLB) caused by Xanthomonas oryzae pv is one of the most widespread devastating diseases of rice worldwide. In this study, a total of 86 indigenous glutinous rice landraces were examined for BLB resistant genes included $X a 4, x a 5$, and $X a 7$ by using molecular markers. The results indicated that 37 samples carrying resistant genes, in which Xa4 was found in 11 samples, $x a 5$ determined in 6 samples, $X a 7$ was in 19 samples, respectively. However, both of $\mathrm{Xa} 7$ and $\mathrm{Xa} 4$ were observed in only one sample. The resistant level against 10 bacterial strains carrying the resistant genes was also evaluated. We found that the number 6,9 , and 8 out of the 10 bacterial strains were resistant to the landraces which carried the Xa4, xa5, and Xa7. The bacterial strain number 5 was revealed highly toxic, causing infection of all samples. The agronomical traits, yield and yield components of 37 rice landraces included the resistant genes ( $X a 4, x a 5$ and $X a 7$ ) were evaluated. Our findings may provide useful genetic sources in indigenous glutinous rice landraces to further develop BLB resistant rice lines via molecular breeding program.
\end{abstract}

\section{Introduction}

Bacterial leaf blights (BLB) disease in rice caused by Xanthomonas oryzae pv.oryzae bacterial, and is one of the most widespread devastating diseases in all rice-cultivating areas of the world. Under the pressure of bacteria infestation, the rice leaves were blighted, severely infected leaves tend to dry promptly, and then the chlorophylls will be non-synthesis, leading to reduce productivity up to $80 \%$. If the disease becomes serious, rice yield can be totally lost. In rice producing countries in Asia, millions of hectares of rice paddies have seriously influenced yearly by infestation of BLB.

Rice (Oryza sativa L.) is the main food and providing daily meals for over 90 million people in Vietnam. According to the report of MARD (2015) [1] BLB was caused severe infestation across the country up to 11.921 ha in both Mekong and Red River Deltas. More seriously, total BLB affected areas in south provinces were 7.069 ha, increased 2.129 ha comparing in 2016 and 110 ha were severely lost [2] (MARD, 2017). Currently, there is no specific treatment for this disease, other synthetic pesticides are being used only to prevent the disease infestation. Therefore, using the resistant varieties are considered as the most feasible solution, which could help for environmentalfriendly and possibly produce safety products instead of using agrochemical pesticides. In order to successfully improve BLB resistant rice varieties, the genetic sources of rice landraces play a key role in controlling this disease. 
To date, total 42 resistant genes to BLB have been reported. Among them, there are 14 recessive genes [3, 4]. In Vietnam, 4 resistant genes including $\mathrm{Xa} 4, \mathrm{xa} 5, \mathrm{Xa}$, and $\mathrm{Xa} 21$ have been reported as the significant resistant genes to pathogenic bacterial strains in the northern Vietnam. These genes have had important role in rice breeding for resistance to BLB. Some markers tightly linked with BLB resistant genes have been identified [5]. Therefore, application of molecular markers to detect genetic resources becomes the way of simple and accurate. Therefore, the objective of this study was to examine a total of 86 Vietnamese indigenous glutinous rice varieties for resistant genes $X a 4, x a 5$, and $X a 7$ by molecular markers. Subsequently, resistant levels of rice varieties carrying the resistant genes were evaluated by applying infection of the 10 bacterial strains. Besides, some major agronomical traits were evaluated to select the best varieties for glutinous rice for molecular breeding.

\section{Materials and Methods}

\section{Plant Materials}

The 86 rice landraces were kindly provided by the Center for Conservation and Development of Crop Genetics Resources (CCD-CGR), Vietnam National University of Agriculture were used in this study. The 10 pathogenic bacterial strains of BLB were collected in the northern Vietnam were used in this study as shown in Table 1.

Table 1. List of pathogenic bacterial strains of BLB.

\begin{tabular}{cllll}
\hline No. & Strain & Code & Isolated & Gathering location \\
\hline 1 & Strain 1 & HUA 01043 & TN 13-4 & Soc Son, Ha Noi \\
2 & Strain 2 & HUA 0020131-1 & Khangdan & Dong Trieu, Quang Ninh \\
3 & Strain 3 & HUA 0020131-2 & Khangdan & Dong Trieu, Quang Ninh \\
4 & Strain 4 & HUA 020361 & Neptan & Thuan Chau, Son La \\
5 & Strain 5 & HUA 02012 & Tethom & Đong Anh, Ha Noi \\
6 & Strain 6 & HUA 010081 & Bacthom7 & Binh Giang, Hai Duong \\
7 & Strain 7 & HUA 020020-2 & Nep87 & Xuan Truong, Nam Dinh \\
8 & Strain 8 & HUA 020083 & Bacthom7 & Quynh Luu, Nghe An \\
9 & Strain 9 & HUA 020020-1 & Nep87 & Xuan Truong, Nam Dinh \\
10 & Strain 10 & HUA 020131-3 & Khangdan & Dien Chau, Nghe An \\
\hline
\end{tabular}

The molecular markers were used to detect the resistant genes $X a 4, x a 5$, and $X a 7$ including the information of sequence, genes, markers and chromosomes were shown in Table 2.

Table 2. The list of genes and markers were used in this study.

\begin{tabular}{|c|c|c|c|c|}
\hline $\begin{array}{l}\text { Linkage } \\
\text { gene }\end{array}$ & Marker & Chr. & Sequences 5'-3' & Author \\
\hline$X a 4$ & Npb181 & 11 & $\begin{array}{l}\text { F: ATCGATCGATCTTCACGAGG } \\
\text { R: GTGCTATAAAAGGCATTCGGG }\end{array}$ & {$[6]$} \\
\hline$x a 5$ & RM122 & 5 & $\begin{array}{l}\text { F: GAGTCGATGTAATGTCATCAGTGC } \\
\text { R: GGAAGGAGGTATCCGCTTTGTTGGAC }\end{array}$ & [7] \\
\hline$X a 7$ & P3 & 6 & $\begin{array}{l}\text { F: CAG CAA TTC ACT GGA GTA GTG GTT } \\
\text { R: CAT CAC GGT CAC CAC CAT ATC GGA }\end{array}$ & [8] \\
\hline
\end{tabular}

Methods

Application of molecular marker to detect resistant genes $\mathrm{Xa4}, \mathrm{xa} 5$ and $\mathrm{Xa} 7$

DNA extraction

Total DNA extraction was carried out according to the process of Zheng et al. [9]. The young leaves were chopped at $2 \mathrm{~cm}$ and crushed in $800 \mu \mathrm{l}$ of mixed solution $(200 \mathrm{mM}$ Tris- $\mathrm{HCl} \mathrm{pH}$ 8.0 buffer; $25 \mathrm{mM}$ EDTA; $250 \mathrm{mM} \mathrm{NaCl}, 0.5 \mathrm{SDS}$ ) in order to break the cells. Fine hundred $\mu 1$ of 
crushing solution were transferred into the test tube $(1.5 \mathrm{ml})$ and added $700 \mu \mathrm{l}$ of mixture (with the ratio of phenol:chloroform:isoamyl alcohol are 25:24:1, respectively). The mixture was slightly shaken and centrifuged for $5 \mathrm{~min}$ at $13.000 \mathrm{rpm}$ and $4^{\circ} \mathrm{C}$. The supernatant was then transferred into the new test tube, added $800 \mu \mathrm{l}$ of ethanol $100 \%$, and centrifuged for $5 \mathrm{~min}$ for $13.000 \mathrm{rpm}$ at $4^{\circ} \mathrm{C}$. The precipitated DNA extracts were collected, cleaned by ethanol $70 \%$ and naturally dried. The precipitated DNA extracts were dissolved in $50 \mu \mathrm{TE}$ and stored at $-20^{\circ} \mathrm{C}$ for next use.

\section{PCR performance}

PCR performance was carried out with the volume of $20 \mu$ including: $10 \mu \mathrm{l}$ PCR master mix $(2 \mathrm{X})$ provided by Promega company, $1 \mu \mathrm{l}$ Primer Forward $(1.0 \mathrm{pmol} / \mathrm{ul}), 1 \mu \mathrm{l}$ Primer Reverse (1.0 pmol/ul), $1 \mu \mathrm{l}$ total DNA and $7 \mu \mathrm{l}$ nuclease-Free water. PCR Performances of genes Xa4, xa5, and $\mathrm{Xa} 7$ were performed as follows: $94^{\circ} \mathrm{C}$ for $4 \mathrm{~m}, 30$ cycles: $94^{\circ} \mathrm{C}$ for $1 \mathrm{~min}, 56^{\circ} \mathrm{C}$ for $1 \mathrm{~min}, 72^{\circ} \mathrm{C}$ for $2 \mathrm{~min}$, and $72^{\circ} \mathrm{C}$ for $7 \mathrm{~min}$. Electrophoresis of PCR products were performed on agarose gel $1.5 \%, 100 \mathrm{~V}$ for $45 \mathrm{~min}$. Gel was dyed with Ethidium Bromide $0.5 \mu \mathrm{g} / \mathrm{ml}$ and observed by UV scanner.

\section{Evaluation of the agronomical traits}

\section{Investigation of rice landraces}

The rice samples were grown in the paddy field according to the conventional methods. Each landrace was cultivated in an area of $5 \mathrm{~m}^{2}$ with the density of $11 \mathrm{~cm} \times 20 \mathrm{~cm} \times 30 \mathrm{~cm}$. The agronomic traits were evaluated following the method of IRRI [10] and QCVN 01-55: 2011/BNNPTNT such as: number of panicles per plant (NPP), filled grains per panicle (FGP), grain weight (GW-P1000), plant height (PH), days to heading (DTH) and some characteristics involving in quality were also recorded.

\section{Experiment of artificial infection}

Artificial infection was carried out at the time that rice plant started booting stage by cutting at $3-5 \mathrm{~cm}$ of leaf. The bacteria were cultured on Wakimoto medium for $48 \mathrm{~h}$. The concentration of bacterial solution was about $10^{8}-10^{9}$ cells $/ \mathrm{ml}$. Whole green leaves of each plant were also cut. Resistant ability of each variety was evaluated by measuring the lesion length after 20 days of infection following the IRRI standards [10] as follows: lesion length $<8 \mathrm{~cm}$ : resistance (R); from 8$12 \mathrm{~cm}$ : medium (M); and $>12 \mathrm{~cm}$ : susceptibility $(\mathrm{S})$.

\section{Results and Discussion}

\section{Detection of resistant gene $\mathrm{Xa4}$}

The indigenous rice landraces have been cultivated and undergone a long time for domestification. Therefore, they have had many valuable agronomic characteristics such as: high yield potential (grains per panicle), high quality, strong tolerance to abiotic and biotic stresses, especially resistance to pests and diseases. In order to exploit them for rice breeding, it is initially examine for BLB resistant genes. In this research, we investigated the ocurrence of Xa4, $x a 5$ and $\mathrm{Xa} 7$ in the 86 rice landraces. According to report of Ton et al. [5], Xa4 gene was determined the resistance to 6/10 leaf blight bacterial strains in the nothern Vietnam. This gene is located on the chromosome 11 which is tightly linked with the marker Npb181 and marker MP [6], respectively. Npb181 marker was used to detect Xa4 gene. PCR product was electrophoresised on agarose gel $1.5 \%$. Rice landraces containing $X a 4$ gene showed a DNA band with the size of 150 base pair (bp). Otherwise, the landraces with non-carrying $\mathrm{Xa} 4$ gene which displayed a DNA band with the size of $120 \mathrm{bp}$ fragment as corresponding to the negative line IR24. The result of electrophoresis of PCR products disclosed that 11 glutinous rice varieties which had $\mathrm{Xa} 4$ gene in the total of 86 samples as shown in Fig. 1. Recently, Ullah et al [11] reported that Xa4 was detected in Basmati-385 and Basmati 2000 cultivars by using STS markers, which was agreed with our current study. In Vietnam, there are sporadical work examining BLB resistant genes of rice landstrains. In much 
effort has been paid on developing the BLB resistant cultivars since 1970 by using Xa4 gene. Some cultivars carrying $\mathrm{Xa} 4$ were reported such as CR203, MT [12].

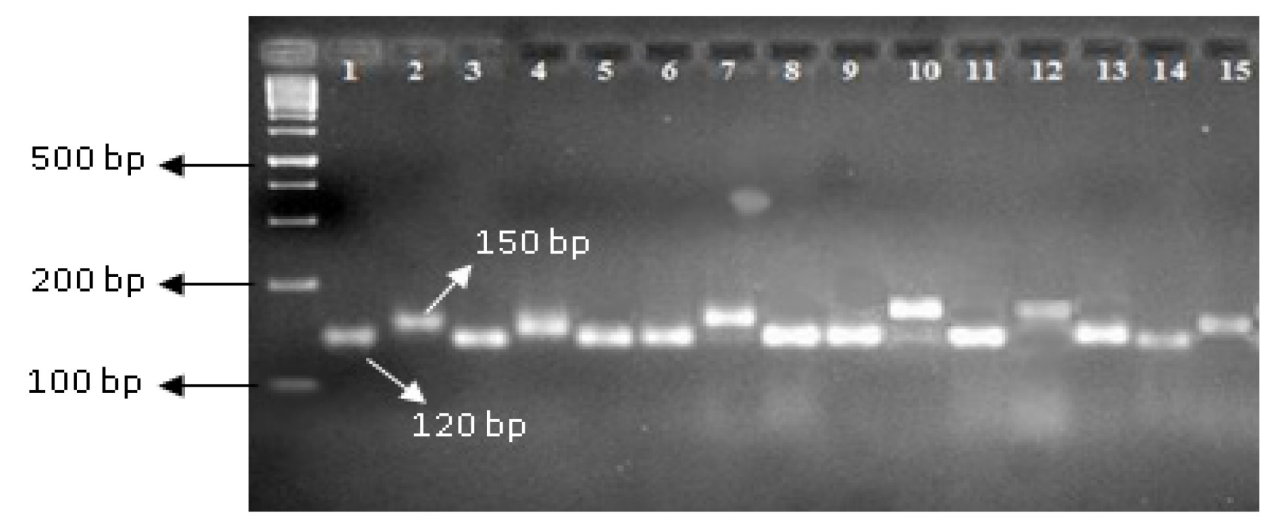

Figure 1. Electrophoresis of PCR-products to detect Xa4 gene using Npb181 marker Lane 1: IR24 (Negative control); lane 2: IRBB4 (Positive control); Lane 3-15: glutinous rice varieties.

\section{Detection of resistant gene $x a 5$}

The recessive gene $x a 5$ is considered as the best resistant gene against BLB. This gene involves in the resistance to 9/10 leaf blight bacterial strains existing in the North of Vietnam [5]. Two markers were previously identified that tightly linking with this gene including RG556 [13] and RM122 [7]. In order to identify the resistant gene $x a 5$ using RG556 marker, PCR products must be cut by restriction enzymes DraI. Otherwise $x a 5$ can be detected directly from PCR products using RM122 marker. Basically, two markers have the same accuracy. Therefore, to save time and cost in this study, RM122 marker was used to detect xa5 gene. The results have shown that the samples carrying the xa5 gene which appears the band with the size of $240 \mathrm{bp}$, the samples with non-containing the $x a 5$ gene displayed a band with the size of $220 \mathrm{bp}$, respectively (Fig. 2). Overall, 6 out of 86 rice landraces carrying the $x a 5$ gene were identified.

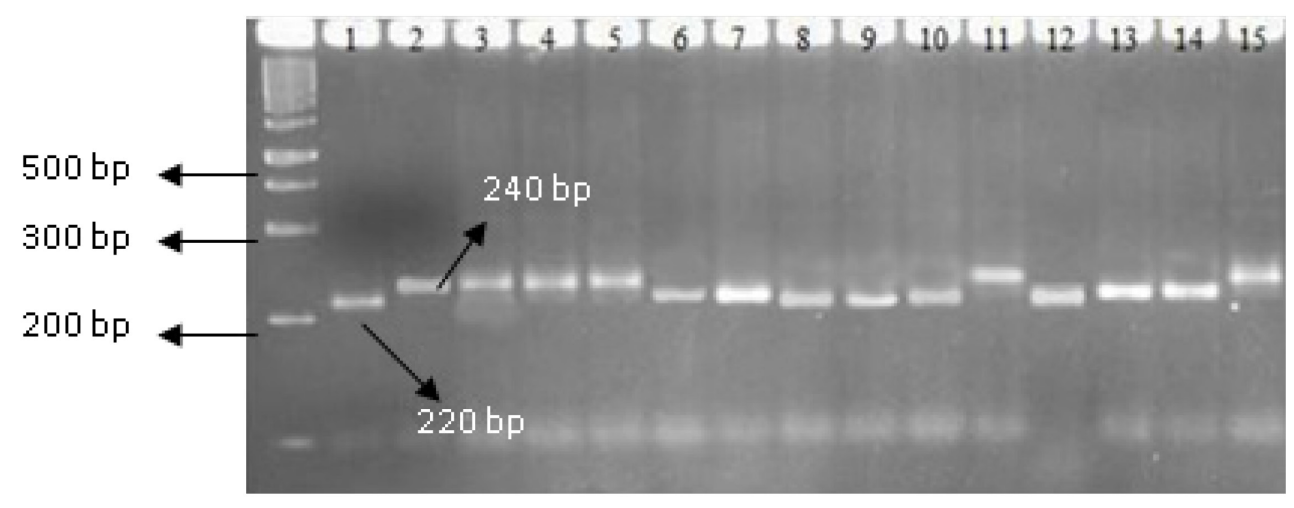

Figure 2. Electrophoresis of PCR products to detect $x a 5$ gene

Lane 1: IR24 (negative control); lane 2: IRBB7 (positive control); Lane 3-15: glutinous rice varieties.

\section{Detection of resistant $X a 7$ gene}

The $\mathrm{Xa} 7$ gene is dominant gene and considered as responsible for greater resistance level to $8 / 10$ bacterial strains in the northern Vietnam [5]. Some markers have been found that tightly linking with this resistant gene such as P3 marker [8], RM5509 marker [13], M5 marker [14]. In Vietnam, P3 marker is widely used to screen and detect the $\mathrm{Xa} 7$ resistant gene. By using this marker, PCR products of the landraces containing $X a 7$ gene which were shown a band with the size of $262 \mathrm{bp}$ after electrophoresis, the varieties with non-containing this gene appears a band with the 
size of 297 bp (Fig. 3). The result of electrophoresis has shown that 19/86 glutinous rice varieties having $X a 7$ gene. Only one rice landrace, Pe con Lam (lua nep) carrying both $X a 4$ and $X 7$ genes (Table 3). Previously, some single dominant genes codes for resistance to $X o$, were reported in some varieties such as Di Huong HD, Dai Duc 65, Canh Nong HB, Mai Khua TB, IR20 and IR22 [12].

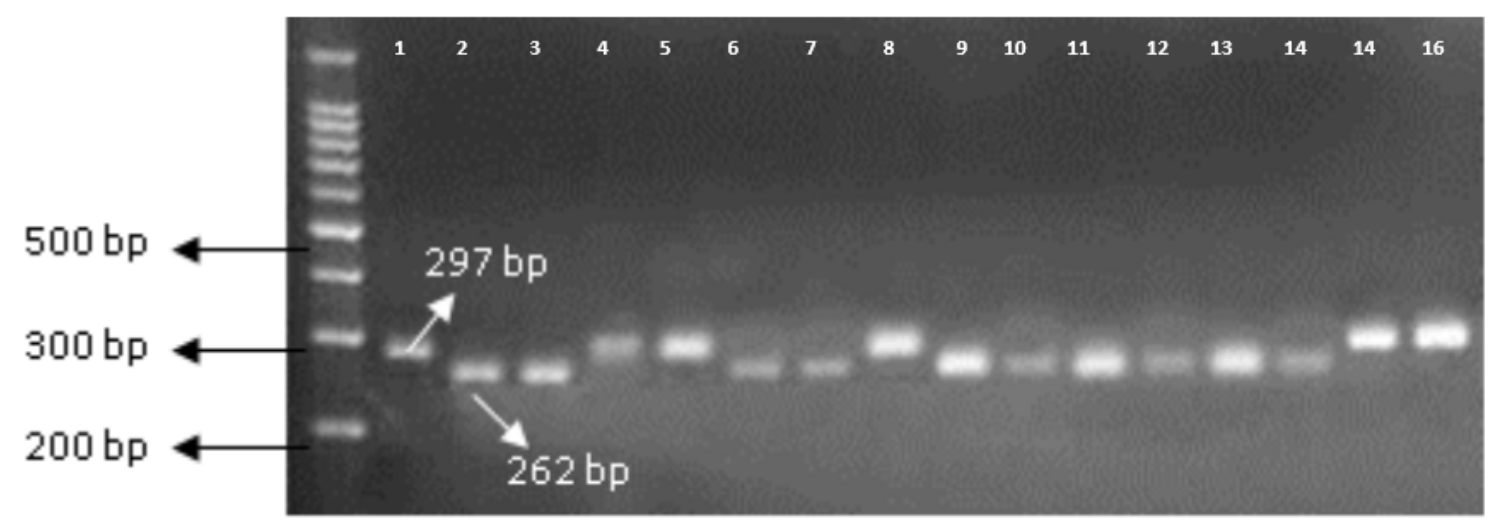

Figure 3. Electrophoresis of PCR products to detect $\mathrm{Xa} 7$ gene

Lane 1: IR24 (Negative control); lane 2: IRBB24 (Positive control);

Lane 3-15: glutinous rice varieties.

Table 3. Results of PCR performance to detect $\mathrm{Xa} 4, \mathrm{Xa} 5$ and $\mathrm{Xa} 7$ resistant genes to BLB.

\begin{tabular}{clcccclccc}
\hline No. & \multicolumn{1}{c}{ landrace } & $\boldsymbol{X a 4}$ & $\boldsymbol{x a 5}$ & $\boldsymbol{X a} \mathbf{a}$ & No. & \multicolumn{1}{c}{ Landrace } & $\boldsymbol{X a 4}$ & $\boldsymbol{x a 5}$ & $\boldsymbol{X a} 7$ \\
\hline 1 & Nep Van & - & - & - & 44 & Nep pelanh $(2)$ & - & - & + \\
2 & Nep hoa vang & - & - & - & 45 & Lua nep bong tron & + & - & - \\
3 & Bong tranh & + & - & - & 46 & Nep, Khau bong tron & - & + & - \\
4 & Lua Thua & - & - & - & 47 & Nep Cam (suoi thin) & - & - & - \\
5 & Lua rang do & - & - & - & 48 & Nep Cam (Chieng pa) & - & - & - \\
6 & Lua re do & - & - & + & 49 & Nep Som (Khau Vang) & - & - & - \\
7 & Lua se & - & - & + & 50 & Nep Cam (ta luong) & - & - & - \\
8 & Nam vang & - & - & - & 51 & Nep thom hat to & - & - & - \\
9 & Nep ca ro & - & - & - & 52 & Nep Thom hat nho & - & - & + \\
10 & Nep co pa & - & - & - & 53 & Nep Vang & - & - & + \\
11 & Nep do & - & - & + & 54 & Nep Nati & - & - & + \\
12 & Nep mo & - & - & + & 55 & Nep ve & + & - & - \\
13 & Nep mui & - & + & - & 56 & Pe con lam (lua nep) & + & - & + \\
14 & Nep muong & - & - & - & 57 & Pe lon (lua nep) & - & - & + \\
15 & Nep non tre & - & - & - & 58 & Nep Plenh cau & - & - & + \\
16 & Nep quan & - & - & + & 59 & Plenh lam & - & + & - \\
17 & Nep ruoi & + & - & - & 60 & Planh meo & - & - & - \\
18 & Nep sap & - & - & - & 61 & Plenh do & + & - & - \\
19 & Nep som & - & - & - & 62 & Lua loc nep cam & + & - & - \\
20 & Nep thap & - & - & - & 63 & Nep cam (Phu Yen) & - & - & - \\
21 & Nep trang & - & - & - & 64 & Pau cam & - & - & - \\
22 & Nep oc & - & - & + & 65 & Khau cam & - & - & - \\
23 & Nep xap & - & - & + & 66 & Khau cam pi & - & - & - \\
24 & Nep cai Hai Duong & - & - & - & 67 & Lo cam & - & - & + \\
25 & Nep den & - & + & - & 68 & Nep cam nuong & - & - & - \\
26 & Nep hom & - & - & - & 69 & Khau cam panh & + & - & - \\
27 & Nep nut & - & - & - & 70 & Nep cam den & - & + & - \\
28 & Lua ngoi & - & - & - & 71 & Nep cam (ban cam) & - & - & - \\
29 & Nep Cam tim & + & - & - & 72 & Nep cam (ruot tim) & - & - & - \\
30 & Nep cai hoa trang & - & - & - & 73 & Nep cam (vo tim) & - & - & - \\
\hline & & & & & & & &
\end{tabular}




\begin{tabular}{llllllllll}
\hline 31 & Deo dang & + & - & - & 74 & Nep cam (Vo trang) & - & - & - \\
32 & Nep rau & - & - & + & 75 & Khau cam pung & + & - & - \\
33 & Nep loc nuong & - & - & + & 76 & Beo ta cam & - & - & - \\
34 & Nep hat may & - & - & + & 77 & Nep nuong (Son La) & - & - & - \\
35 & Khau tan pom & + & - & - & 78 & Nep 44 & - & - & - \\
36 & Khau tan hang & - & - & - & 79 & Nep TK90 & - & - & - \\
37 & Khau tan nuong & - & - & + & 80 & Nep 97 & - & - & - \\
38 & Nep ran & - & + & - & 81 & Nep 87 & - & - & - \\
39 & Dang chiem & - & - & - & 82 & Nep 352 & - & - & - \\
40 & Lua ma & - & - & - & 83 & Nep nhung & - & - & - \\
41 & Nep chin som & - & - & - & 84 & Nep lang lieu & - & - & - \\
42 & Lua nep Tang San & - & - & - & 85 & Nep cau & - & - & - \\
43 & Lua nep, Pelenh & - & - & + & 86 & Nep qua vai & - & - & + \\
\hline
\end{tabular}

Note: “+”: Landrace containing resistant gene; “-”: Landrace non-containing resistant gene

\section{Evaluation of BLB resistant samples}

Currently, there were over ten existing bacterial strains in the north of Vietnam [3]. These strains are being stored at Faculty of Biotechnology, Vietnam National University of Agriculture. In this research, 10 bacterial strains were used to examine resistant level to BLB. The results demonstrated that the landraces containing $\mathrm{Xa} 4$ gene had similar resistant level to IRBB4 control variety (containing $\mathrm{Xa} 4$ gene). These landraces had resistant activity against $6 / 10$ bacterial strains including the strains number 2, 5, 6, 7, 9, and 10, respectively. The other landraces containing xa5 resistant gene which had similar resistant level to control variety (carrying xa5 gene). These landraces were resistant against 9/10 bacterial strains except the bacterial strain number 5 . The containing $\mathrm{Xa} 7$ resistant gene also had similar resistant ability to control variety (carrying $\mathrm{Xa} 7$ gene). These varieties were resistant to $8 / 10$ bacterial strains, they were infected by only the two strains including number 4 and 5 , respectively.

In general, almost the rice landraces with non-containing resistant genes to BLB were seriously infected by all the 10 bacterial strains or some strains out of the 10 studied strains (Figs. 4A, 4B, 4C and 4D). Additionally, the bacterial strain number 5 had the strongest toxicity, causing infection to all samples which carried three resistant genes. It noted that only carrying $x a 5$ gene landraces showing resistant to the number 4 bacterial strains. Our results have been agreed with the previous of Ton et al. (2013) who reported that the number 4 and 5 bacterial strains were shown highly toxic

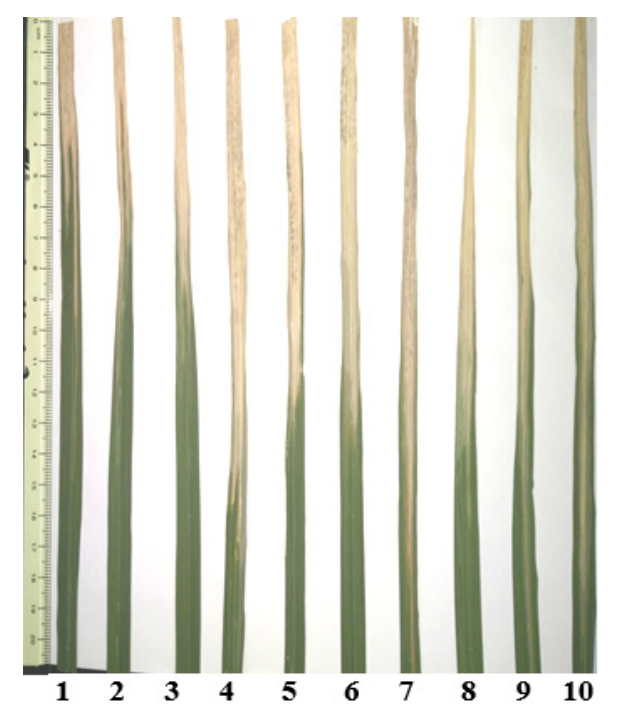

Figure 4A. The symptom of control rice variety IR2 4 under the infection of the 10 bacterial strains.

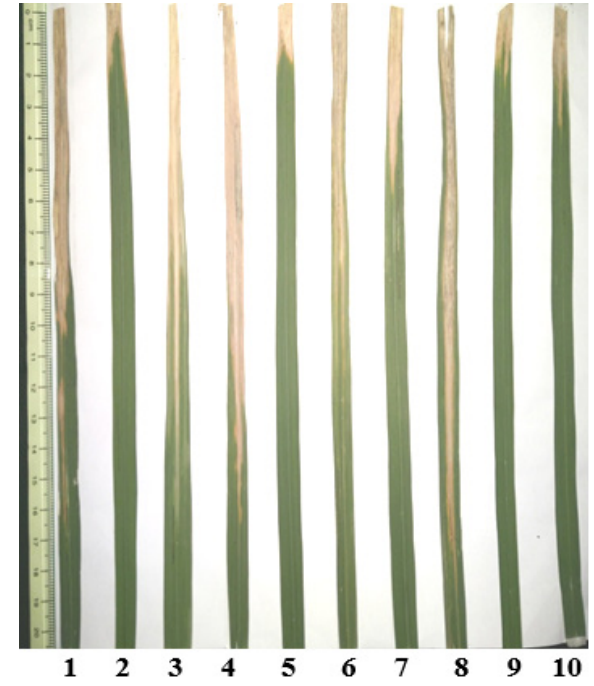

Figure 4B. The response of the rice variety containing $\mathrm{Xa} 4$ under the infection of 10 bacterial strains. 


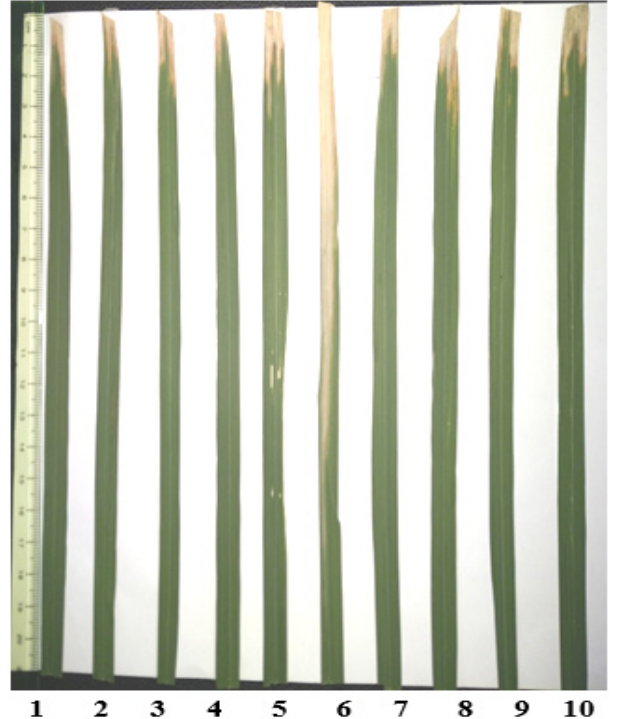

Figure 4C. The response of the rice variety containing $x a 5$ under the infection of 10 bacterial strains.

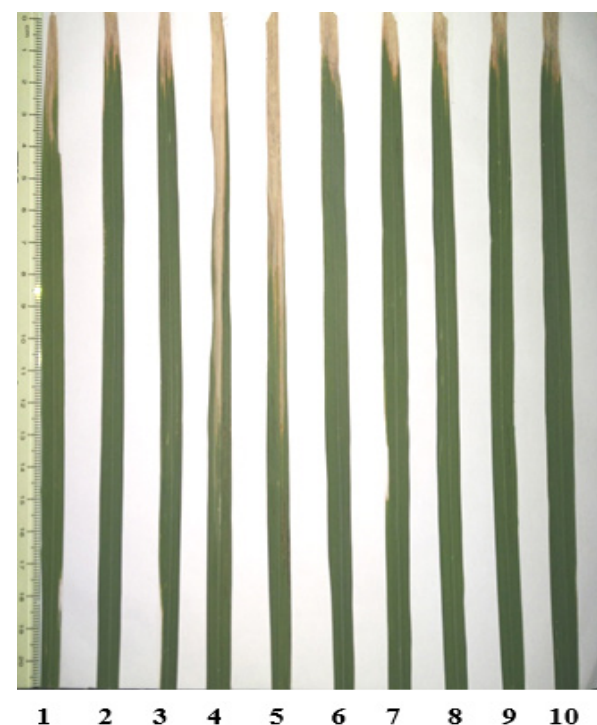

Figure 4D. The response of the rice variety containing $\mathrm{Xa} 7$ under the infection of 10 bacterial strains.

\section{Agronomic traits of some landraces carrying resistant genes}

In order to effectively exploit some major agronomical characteristics of each genetic source were evaluated including some major traits: days to heading (DTH), plant height (PH), a number of panicle per plant (NPP), number of grains per panicle (NGP), grain weight (GW-P1000), individual yield (IY) were evaluated. The results showed that the 37 rice landraces containing resistant genes to BLB, then were evaluated their agronomic traits in spring season crop, 2016 to provide further comprehensive information for effective exploitation these genetic resources as shown in Table 4.

Table 4. Agronomic traits of the glutinous rice landraces carrying resistant genes to BLB.

\begin{tabular}{|c|c|c|c|c|c|c|c|c|c|}
\hline No. & Landrace & $\begin{array}{c}G D \\
(\text { days })\end{array}$ & $\begin{array}{c}P H \\
(\mathrm{~cm})\end{array}$ & $N P P$ & $T G$ & $\begin{array}{c}\text { PFGP } \\
\text { (\%) }\end{array}$ & $\begin{array}{c}G W \\
(g)\end{array}$ & $\begin{array}{l}I Y \\
(g)\end{array}$ & $C G$ \\
\hline 1 & Bong tranh & 138 & $140.5 \pm 4.0$ & 5.0 & 139.8 & 76.9 & 28.0 & 13.6 & Xa4 \\
\hline 2 & Lua re do & 132 & $108.2 \pm 2.3$ & 4.6 & 102.6 & 60.7 & 24.0 & 9.5 & $X a 7$ \\
\hline 3 & Lua se & 133 & $101.0 \pm 2.4$ & 4.2 & 137.6 & 76.9 & 28.5 & 13.5 & $X a 7$ \\
\hline 4 & Nep do & 131 & $100.5 \pm 2.8$ & 4.4 & 143.6 & 63.2 & 32.0 & 10.5 & $X a 7$ \\
\hline 5 & Nep mo & 132 & $132.0 \pm 4.1$ & 4.6 & 85.8 & 55.1 & 32.0 & 11.3 & $X a 7$ \\
\hline 6 & Nep mui & 133 & $148.6 \pm 4.5$ & 5.0 & 81.2 & 66.5 & 32.5 & 11.4 & $x a 5$ \\
\hline 7 & Nep ruoi & 136 & $132.4 \pm 3.6$ & 6.4 & 190.4 & 76.9 & 29.0 & 11.5 & $X a 4$ \\
\hline 8 & Nep oc & 139 & $145.6 \pm 6.1$ & 5.0 & 126.2 & 48.5 & 28.5 & 9.4 & $X a 7$ \\
\hline 9 & Nep xap & 132 & $138.8 \pm 3.7$ & 6.2 & 148.2 & 69.8 & 32.5 & 14.6 & $X a 7$ \\
\hline 10 & Nep Den & 133 & $142.0 \pm 5.2$ & 6.4 & 116.6 & 65.9 & 28.0 & 13.5 & $x a 5$ \\
\hline 11 & Nep Cam tim & 133 & $154.8 \pm 5.5$ & 5.8 & 184.8 & 65.7 & 28.0 & 15.7 & Xa4 \\
\hline 12 & Deo dang & 146 & $143.5 \pm 4.3$ & 4.4 & 171.4 & 78.3 & 24.3 & 12.4 & Xa4 \\
\hline 13 & Nep rau & 143 & $120.2 \pm 4.7$ & 4.2 & 116.0 & 63.8 & 40.3 & 12.9 & $X a 7$ \\
\hline 14 & Nep loc nuong & 144 & $145.8 \pm 6.2$ & 5.8 & 97.6 & 69.7 & 21.3 & 7.5 & $X a 7$ \\
\hline 15 & Nep hat may & 144 & $156.4 \pm 5.5$ & 5.4 & 187.2 & 71.0 & 21.6 & 9.6 & $X a 7$ \\
\hline 16 & Khau tan pom & 143 & $124.2 \pm 3.6$ & 4.8 & 159.4 & 75.9 & 20.6 & 10.6 & Xa4 \\
\hline 17 & Khau tan nuong & 132 & $133.6 \pm 2.3$ & 5.6 & 178.0 & 77.0 & 24.5 & 14.2 & $X a 7$ \\
\hline 18 & Nep ran & 132 & $136,6 \pm 3.4$ & 5.2 & 170.2 & 78.1 & 25.5 & 11.5 & $x a 5$ \\
\hline 19 & Lua nep, Pelenh & 142 & $128.6 \pm 3.9$ & 4.2 & 208.6 & 51.3 & 24.4 & 11.5 & $X a 7$ \\
\hline 20 & Nep pelanh (2) & 136 & $141.8 \pm 4.7$ & 6.2 & 124.8 & 71.6 & 15.4 & 8.8 & $X a 7$ \\
\hline 21 & Lua nep bong tron & 138 & $157.2 \pm 5.1$ & 6.8 & 107.2 & 87.7 & 28.5 & 12.6 & Xa4 \\
\hline 22 & Khau bong tron & 135 & $163,6 \pm 5.5$ & 4.8 & 118.8 & 76.1 & 28.8 & 10.1 & $x a 5$ \\
\hline
\end{tabular}




\begin{tabular}{lllllllllc}
\hline 23 & Nep Thom hat nho & 137 & $155.8 \pm 2.5$ & 6.4 & 132.6 & 86.4 & 20.8 & 11.7 & Xa7 \\
24 & Nep Vang & 134 & $140.2 \pm 3.8$ & 7.0 & 166.4 & 75.1 & 27.9 & 16.8 & Xa7 \\
25 & Nep Nati & 135 & $108.2 \pm 2.4$ & 4.0 & 170.6 & 59.6 & 28.5 & 10.3 & Xa7 \\
26 & Nep ve & 132 & $123.5 \pm 3.2$ & 5.4 & 186.4 & 69.6 & 29.5 & 17.2 & Xa4 \\
27 & Pe con lam & 132 & $132.5 \pm 3.5$ & 4.0 & 210.5 & 64.8 & 32.5 & 11.5 & Xa4/Xa7 \\
28 & Pe lon (lua nep) & 142 & $143.9 \pm 4.0$ & 7.6 & 127.2 & 68.2 & 32.5 & 17.5 & Xa7 \\
29 & Nep Plenh cau & 146 & $136.2 \pm 4.4$ & 5.4 & 144.4 & 75.9 & 28.7 & 14.2 & Xa7 \\
30 & Plenh lam & 140 & $131.8 \pm 4.6$ & 5.0 & 105.8 & 67.7 & 36.4 & 14.5 & xa5 \\
31 & Plenh do & 147 & $126.6 \pm 2.6$ & 5.8 & 152.5 & 83.2 & 24.4 & 15.3 & Xa4 \\
32 & Lua loc nep cam & 146 & $104.5 \pm 2.5$ & 4.6 & 113.2 & 79.5 & 36.5 & 13.5 & Xa4 \\
33 & Lo cam & 134 & $136.1 \pm 3.2$ & 6.2 & 209.6 & 56.6 & 28.1 & 17.3 & Xa7 \\
34 & Khau cam panh & 140 & $152.5 \pm 4.5$ & 5.0 & 173.6 & 74.2 & 28.5 & 13.6 & Xa4 \\
35 & Nep cam den & 142 & $142.6 \pm 4.5$ & 4.8 & 149.4 & 76.0 & 32.3 & 13.5 & xa5 \\
36 & Khau cam pung & 142 & $135.8 \pm 5.1$ & 4.6 & 60.2 & 67.4 & 32.4 & 10.1 & Xa4 \\
37 & Nep qua vai & 135 & $134.5 \pm 3.9$ & 5.3 & 117.3 & 76.8 & 24.3 & 9.8 & Xa7 \\
\hline GD: $:$ Growth Duration, PH: Plant height, NPP: Number of panicle per plant, TG: Total grain, \\
PFGP: Percentage of full-filled grain per plant, GW: Grain weight, IY: Individual yield, CG: \\
Containing gene
\end{tabular}

Regarding the growth duration, the growth duration of 37 samples was ranged from 131 to 146 days. In which, 17 landraces were grouped into short growth duration (115 to 135 days). The other landraces were grouped into medium growth duration (136 to 160 days). For plant height, there were 7 rice landraces in medium height $(90$ to $125 \mathrm{~cm})$. The other landraces were rather high with the height of more than $125 \mathrm{~cm}$. The number of panicles per plant was ranged from 4.0 to 7.6 panicles. The number of grains per panicle was from 60.2 to 210 grains/panicle. Some rice landraces had extremely big panicles such as: Lua nep Pelenh, Pe con lam, Lo cam and nep roi. For the total grains (P1000), the glutinous rice landraces mostly had very high weight, some samples had P1000 up to over $36 \mathrm{~g}$, especially was $40.3 \mathrm{~g}$ found in Nep rau. In the case of individual yield, it was ranged from $7.5 \mathrm{~g}$ to $17.3 \mathrm{~g}$, which was shown significantly high. This is an extremely valuable material sources, which should be exploited and managed for future rice breeding program.

\section{Conclusions}

Among the total of 86 rice landraces, 11 samples carrying $\mathrm{Xa} 4$ gene, 6 landraces were detected $x a 5$ gene, 19 landraces possessed $\mathrm{Xa} 7$ gene and 1 rice landrace carried both of the $\mathrm{Xa} 4$ and $\mathrm{Xa} 7$ genes were identified by using molecular markers. The evaluation of resistant level of rice varieties to BLB using 10 bacterial strains indicated that $X a 4$ gene involved in resistance to $6 / 10$ strains, $X a 5$ gene involved in resistance to $9 / 10$ strains and $X a 7$ gene involved in resistance to $8 / 10$ strains of bacteria. The bacterial strain number 5 had the strongest toxicity. The evaluation of agronomic traits of the 37 samples included the resistant genes rice landraces disclosed that they are precious source of materials for glutinous rice breeding program of resistance to BLB disease.

\section{References}

[1] MARD - Ministry of Agriculture and Rural Development, The final report of pests and disease infestation in plant, No.29/TBSB-BVTV-TV, 2015.

[2] MARD -PPD - Ministry of Agriculture and Rural Development - Plant Protection Department, Annual Report on plant diseases, No: 6/TBSB-BVTV, 2017.

[3] S. Chen et al., Genetic analysis and molecular mapping of a novel recessive gene $x a 34(\mathrm{t})$ for resistance against Xanthomonas oryzae pv. oryzae, Theor. Appl. Genet. 122(7) (2011) 13311338. 
[4] C.S. Wang, D.G. Lin, The application of genomic approaches in studying a bacterial blight reistant mutant in rice, in: J. Li (Ed.), Advances in International Rice Research, Intech Publisher, 2017.

[5] P.H. Ton, T.V. Hai, N.V. Hung, Research genetically diversity of bacterial leaf blight strains in Vietnam, Nat Confer Vietnam plant dis. (2012) 73-81.

[6] S.R. Yoshimura et al., RFLP mapping of the bacterial blight resistance genes $X a-3$ and $X a-4$, Rice.Genet. Newsl. 9 (1992) 136-138.

[7] M.W. Blair, S.R. McCouch, Microsatellite and sequence-tagged site markers diagnostic for the rice bacterial leaf blight resistance gene $x a-5$, Theor. Appl. Genet. 95(1) (1997) 174-184.

[8] S. Taura, Y. Sugita, D. Kawahara, Gene distribution resistance to bacterial blight in Northern Vietnam rice varieties, Abstracts of the $1^{\text {st }}$ Inter. Confer. Bacterial. Blight of Rice, March 1719, 2004, Tsukuba, Japan.

[9] J.S. Zheng, B. La, PCR technique and its practical mothods, Mol. Plant Breed. 1(3) (2003) 381-394.

[10] IRRI- International Rice Research Institute, Standard evaluation system for rice (SES), IRRI Publisher, 2002.

[11] I. Ullah et al., Detection of bacterial blight resistance genes in basmati rice landstrains, Genet. Mol. Res. 11(3) (2012) 1960-1966.

[12] T.M. Son, Breeding rice cultivars resistant to bacterial leaf blight (Xanthomonas campestris pv.oryzae) in Vietnam, in: T. Jacobs, J.E. Parlevliet (Eds.), Durability of disease resistance. Current plant Science and Biotechnology in Agriculture, vol. 18, Springer Publisher, 1993.

[13] S.R. McCouch et al., Development and mapping of 2240 new SSR markers for rice (Oryza sativa L.), DNA Res. 9(6) (2002) 199-207.

[14] B.W. Porter et al., Development and mapping of markers linked to the rice bacterial blight resistance gene Xa7, Crop Sci. 43(4) (2003) 1484-1492. 